\title{
Model Pyrolysis - The Study of Cellulose*
}

\author{
by E. W. Robb1, W. R. Johnson, J. J. Westbrook', and R. B. Seligman
}

Philip Morris Research Center, Richmond, Virginia, USA

\section{INTRODUCTION}

Relating smoke products to smoke precursors when burning any naturally occurring plant material is an ambiguous task, at best. To facilitate interpretation of results a simple, model pyrolysis system was studied using cellulose as the smoke precursot and monitoring benzo(a)pyrene $[B(a) P]$ as the smoke product. Cellulose was ideally suited because its structure and stereochemistry are known; because it was available in pure form; and because it is nonvolatile, it necessarily must decompose on heating thereby contributing to the products of combustion. In addition, cellulose is found abundantly in plants and constitutes more than $16 \%$ of the dry weight of tobacco.

ISOTHERMAL PYROLYSIS EXPERIMENTS

Procedure

Pyrolysis was carried out in a vertically mounted "Vycor ${ }^{\oplus}$ glass tube $\left(2^{\prime \prime} X_{15} 5^{\prime \prime}\right)$ containing Berl saddles which covered a thermocouple at the tube's center. Carrier gas (nitrogen, unless otherwise specified) was introduced at the top of the tube, and pyrolyzate was collected at the lower end' of the tube on either Cambridge filter pads or in cold traps: Usually a carrier gas flow rate of $85 \mathrm{ml}$ per minute was used while heating was controlled by a 220 volt electric furnace. The substance to be pyrolyzed.was introduced at the top of the tube through a powder funnel (under carrier gas) at the rate of 5 grams per 30 minutes.

The pyrolyzate was dissolved in reagent grade acetone and evaporated to dryness on a steam bath, and the residues were dissolved in small volumes of benzene-methanol ( $4: 1$ ). Aliquots were chromatographed on acetylated paper using ethylene glycol monomethyl ether as the developing solvent: The details of the paper chromatographic procedure and subsequent fluorimetric analysis of $B(a) P$. have been published (1). The results of analyses are given as nanograms (ng), of $B(a) P$ formed per gram of cellulose (or other material) pyrolyzed.

\begin{tabular}{|c|c|}
\hline $\begin{array}{l}\text { Pyrolysis temperature } \\
\left({ }^{\circ} \mathrm{C}\right)\end{array}$ & $\begin{array}{c}\text { B(a)P yield } \\
\text { (ng/g cellulose) }\end{array}$ \\
\hline $\begin{array}{l}350 \\
450 \\
500 \\
550 \\
600 \\
650 \\
700 \\
750 \\
775 \\
800 \\
850 \\
880\end{array}$ & $\begin{array}{r}0 \\
60 \\
<100 \\
<1,000 \\
5,000 \\
20,000 \\
16,000 \\
16,000 \\
53,500 \\
76,000 \\
100,000 \\
142,000\end{array}$ \\
\hline
\end{tabular}

$B(a) P$ Yield vs. Temperature The results of the isothermal pyrolysis of cellulose at various temperatures are given in Table 1 . In general, the yield of $B(a) P$ increased with temperature. The yield below $600^{\circ} \mathrm{C}$ was relatively small, between $600^{\circ} \mathrm{C}$ and $750^{\circ} \mathrm{C}$ varied only slightly, and above $750^{\circ} \mathrm{C}$ increased very sharply. These results suggested two independent processes for forming $\mathrm{B}(\mathrm{a}) \mathrm{P}$; one operating below $650^{\circ} \mathrm{C}$ and the other taking effect above $750^{\circ} \mathrm{C}$.

4 Presented at the 4th International Scientific Tobacco Congress, Athens, September 1966. 1 Present address: Department of Chemistry, Stevens Institute of Technology, Hoboken, New Jersey.

2. Present address: International Flavors \& Fragrances Inc., Union Beac, New. Jersey. 
$B(a) P$ Yield vs. Oxygen Concentration When nitrogen was replaced with atmospheres containing oxygen, an unexpected increase in the $\mathrm{B}(\mathrm{a}) \mathrm{P}$ yield resulted (Table 2). This experiment suggests that any attempt to increase the amount of oxygen in an oxygen-deficient pyrolysis zone will not decrease the amount of $B(a) P$ formed there.

TABLE 2

TABLE 4

lsothermal pyrolysis of collulose: Effect of oxygen

\begin{tabular}{c|c|c}
\hline $\begin{array}{c}\text { Pyrolysis } \\
\text { temperature } \\
\left({ }^{\circ} \mathrm{C}\right)\end{array}$ & Carrier gas & $\begin{array}{c}\text { B(a)P yield } \\
\text { (ng/g cellulose) }\end{array}$ \\
\hline 700 & $\begin{array}{l}\text { Nitrogen } \\
700\end{array}$ & $\begin{array}{c}\text { Nitrogen: oxygen } \\
(80: 20)\end{array}$ \\
850 & $\begin{array}{c}\text { Nitrogen } \\
\text { Nitrogen: oxygen } \\
(90: 10)\end{array}$ & 15,000 \\
850 & $\begin{array}{c}114,000 \\
850\end{array}$ & $\begin{array}{c}\text { Nitrogen: oxygen } \\
(80: 20)\end{array}$ \\
\hline
\end{tabular}

TABLE 3

Isothermal pyrolysis of cellulose af $850^{\circ} \mathrm{C}$ in nitrogen:

Effect of motals

\begin{tabular}{l|c}
\hline \multicolumn{1}{c|}{ Metallic sponge } & $\begin{array}{r}\text { B(a)P yield } \\
\text { (ng/g cellulose) }\end{array}$ \\
\hline Nóne & 100,000 \\
Copper (Chore Girl*) & 124,000 \\
Stainless steel (Kurly Kate*) & 900 \\
Iron (steel wool) & 270 \\
\hline
\end{tabular}

Isothermal pyrolysis of cellulose with $10 \%$ additive at $850 \% \mathrm{C}$ in nitrogen

\begin{tabular}{l|c}
\hline \multicolumn{1}{c|}{ Additive } & B(a)P yield (ng/g cellulose) \\
\hline None & 92,000 \\
Tungsten powder & 95,000 \\
Alumina & 80,000 \\
Ceric ammonium nitrate & 65,000 \\
Aluminum t-butoxide & 62,000 \\
Cupric chloride & 59,000 \\
Aluminum hydroxide & 56,000 \\
Zinc peroxide & 50,000 \\
Cupric acetate & 44,000 \\
Aluminum nitrate & 34,000 \\
Vanadium pentoxide & 30,000 \\
Cupric oxide & 30,000 \\
Sodium nitrate & 24,000 \\
Cupric nitrate & 23,000 \\
Nickel acetate & 14,000 \\
Iron powder & 13,000 \\
Ferrous oxalate & 10,000 \\
Nickel powder & 7,600 \\
Nickel oxalate & 6,000 \\
Cobalt powder & 4,800 \\
Ferric oxide & 3,500 \\
Ferrocene & 350 \\
& \\
\hline &
\end{tabular}

* Trade name

$B(a) P$ Yield vs. Additives (at $850^{\circ} \mathrm{C}$ ) To learn the effect of high-surface-area metals on the pyrolysis of cellulose, the padking in the tube was partially replaced by a metallic sponge (scouring pad), see Figure 1 . Cellulose, in contact with these sponges, was pyrolyzed (Table 3). Because nearly complete inhibition of B(a)P formation by the iron sponges was noted, a series of pyrolyses

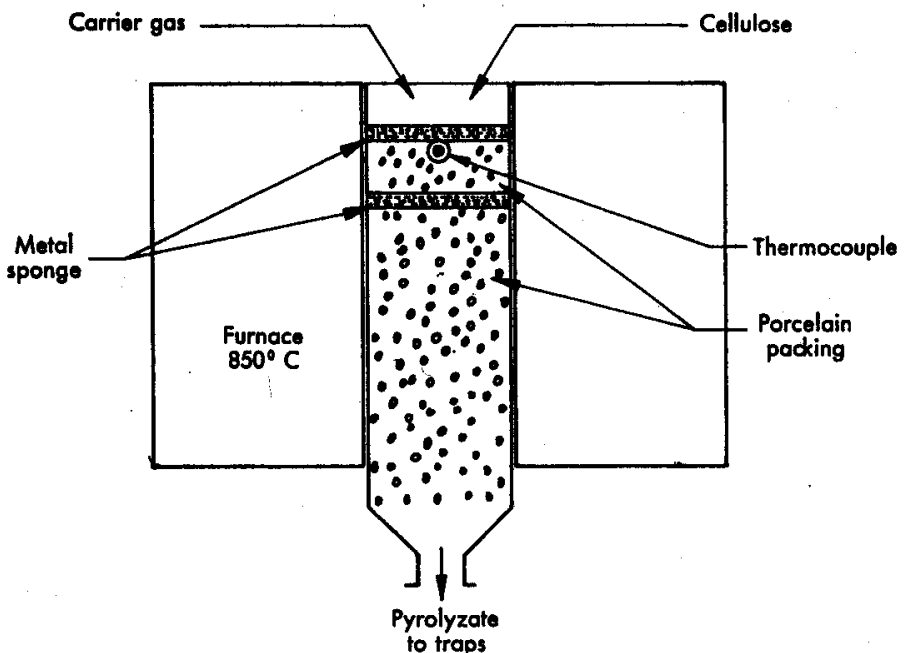

FIGURE 1
Isothermal pyrolysis apparatus were performed in which the cellulose was mixed with one-tenth its weight of various inorganic materials. The results are listed in Table 4.

The conclusions drawn from these isothermal studies were: compounds of the metallic elements were more effective than were the metals themselves; in a salt, the anion exerted some effect with nitrate being the more effective in decreasing $B(a) P$ yield; and of the metallic elements; iron, cobalt, and nickel were the only ones tried which showed any effectiveness. In the case of iron compounds, 
decreased $\mathrm{B}(\mathrm{a}) \mathrm{P}$ yields resulted with all valance states of the metal. In addition, the degree of physical mixing of the inorganic compound with the cellulose appeared unimportant.

The anion and the cation in these salts exerted their effects independently which permitted the calculation of a numerical factor for each anion and cation. Multiplication of these factors by 92,000 (the control value for cellulose) gave a "predicted" value for the B(a)P yield which closely approximated the observed value (Table 5). Note that the factor for aluminium, being greater than one, implies that aluminium has a tendency to increase $B(a) P$ formation. It was apparent that $B(a) P$ was not the only product whose yield was reduced, because the total pyrolyzate which formed abundantly from cellulose at $850^{\circ} \mathrm{C}$ was absent in the celluloseplus-iron experiments. The paper chromatograms in which $B(a) P$ was separated, normally had many fluorescent zones attributed to other polycyclic compounds; the chromatograms of the cellulose-steel wool pyrolyzate had only one faint fluorescent zone which was identified as anthracene.

It was thought that this effect of iron might be occurring only in the absence of oxygen. This was not the case as both iron oxide and steel wool were capable of decreasing $B(a) P$ yield both in air and in nitrogen (Table 6). The effect of water on this cellulose-iron reaction is shown in Table 7. Evidently the presence of water prevented the iron from inhibiting the $\mathrm{B}(\mathrm{a}) \mathrm{P}$ formation.

Finally, the effect of iron at various pyrolysis temperatures was studied. The resulting $B(a) P$ yields are compared with those obtained from cellulose alone in Figure 2. From this we have concluded that this effect of iron begins at about $600^{\circ} \mathrm{C}$, as the difference between the $B(a) P$ yields with and without the iron decreased at the lower temperatures until at temperatures below $600^{\circ} \mathrm{C}$ they were about the same.

\begin{tabular}{|c|c|c|c|c|}
\hline \multicolumn{5}{|c|}{$\begin{array}{l}\text { Anion and cation factors for } B(a) P \text { yield } \\
\text { Predicted } B(a) P \text { yield }=92,000\left(f_{\mathrm{a}}\right)\left(f_{c}\right)\end{array}$} \\
\hline Anion & Factor, $F_{a}$ & \multicolumn{2}{|c|}{ Cation } & Factor, $F_{c}$ \\
\hline $\begin{array}{l}\text { Metal } \\
\text { Acetate } \\
\text { Oxalate } \\
\text { Chloride } \\
\text { Oxide } \\
\text { Nitrate }\end{array}$ & $\begin{array}{l}1.00 \\
0.79 \\
0.68 \\
0.64 \\
0.37 \\
0.28\end{array}$ & \multicolumn{2}{|c|}{$\begin{array}{l}\text { Aluminum } \\
\text { Tungsten } \\
\text { Copper } \\
\text { Sodium } \\
\text { Vanadium } \\
\text { Iron } \\
\text { Nickel } \\
\text { Cobalt }\end{array}$} & $\begin{array}{l}2.19 \\
1.03 \\
1.00 \\
0.93 \\
0.88 \\
0.10 \\
0.09 \\
0.05\end{array}$ \\
\hline 8 & al pyro & & 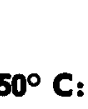 & $\begin{array}{l}\text { TABLE } 6 \\
\text { et of iron. }\end{array}$ \\
\hline \multirow{2}{*}{\multicolumn{2}{|c|}{ Material pyrolyzed }} & \multicolumn{3}{|c|}{$\begin{array}{c}\text { B(a)P yield } \\
\text { (ng/g cellulose) }\end{array}$} \\
\hline & & \multicolumn{2}{|c|}{$\begin{array}{c}\text { Nitrogen } \\
\text { carrier }\end{array}$} & $\begin{array}{l}\text { Air } \\
\text { carrier }\end{array}$ \\
\hline \multicolumn{3}{|c|}{$\begin{array}{l}\text { Cellulose } \\
\text { Cellulose with } 10 \% \text { iron oxide } \\
\text { Cellulose over steel wool }\end{array}$} & $\begin{array}{r}92,000 \\
3,500 \\
300\end{array}$ & $\begin{array}{r}144,000 \\
5,000 \\
7,000\end{array}$ \\
\hline
\end{tabular}

TABLE 7

Isothermal pyrolysis at $850^{\circ} \mathrm{C}$ in nitrogen: Effect of iron plus water

\begin{tabular}{l|c}
\hline $\begin{array}{c}\text { Material pyrolyzed } \\
\text { over steel wool }\end{array}$ & $\begin{array}{c}\text { B(a)P yield } \\
\text { (ng/g cellulose) }\end{array}$ \\
\hline Cellulose & 300 \\
Cellulose:water (6:3) & 44,300 \\
Cellulose:water (6:4) & 76,000 \\
\hline
\end{tabular}

\section{GRADUATED HEATING EXPERIMENTS}

The large amount of $\mathrm{B}(\mathrm{a}) \mathrm{P}$ formed in the isothermal pyrolysis experiments was surprising; and, as noted, much lower $B(a) P$ yields were observed at temperatures below $600^{\circ} \mathrm{C}$. Therefore, this low-temperature, low-efficiency, B(a)P-forming process was studied. The type of experiment chosen was one in which the cellulose was heated from room temperature to $850^{\circ}$. C during a period of several minutes with the pyrolyzate being collected during successive temperature intervals.

Procedure

The same apparatus was used except that the material to be heated was placed in the Vycor glass tube on top of the porcelain padking. After adjusting the carrier gas flow (normally $85 \mathrm{ml}$ per minute) the apparatus was allowed to heat up. In general, 22 minutes was required to bring the apparatus from $30^{\circ} \mathrm{C}$ to $850^{\circ} \mathrm{C}$. The pyrolyzate was collected on Cambridge pads which were changed during the experiment, usually at intervals of $100^{\circ} \mathrm{C}$. 
FIGURE 2

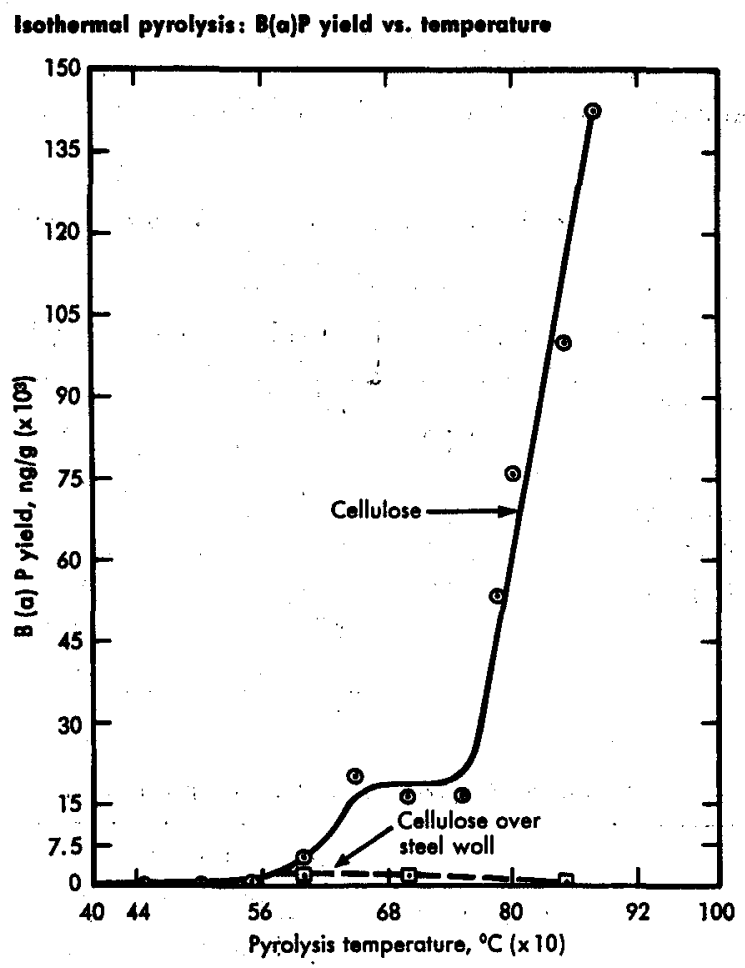

The temperature of the material being pyrolyzed was higher than the recorded temperature, because the apparatus was not in thermal equilibrium while heating and because the heating elements in the furnace were at a much higher temperature than that recorded by the thermocouple. The magnitude of this error was estimated by measuring the temperature at the inner wall of the tube with a separate thermocouple. It was found that the temperature difference between the wall of the tube and the thermocouple could be as great as $100^{\circ} \mathrm{C}$, depending on the temperature and the heating rate.

As $B(a) P$ yields below $350^{\circ} \mathrm{C}$ were negligible, it was felt that the total yield of $B(a) P$ collected from $350^{\circ} \mathrm{C}$ to $850^{\circ} \mathrm{C}$ was the most significant figure. Therefore, yields of $\mathrm{B}(\mathrm{a}) \mathrm{P}$ collected in the individual temperature ranges are given only when they are of special interest.

Results and Discussion

Effect of Flow Rate As seen in Table 8 increased carrier gas How rate caused an increase in $B(a) P$ yield; however, the total yields were much lower than those encountered in the iso-

TABLE 8

Groduated heating of cellulose in nitrogen: Flow rate vs. B(a)P yield

\begin{tabular}{c|c}
\hline $\begin{array}{c}\text { Carrier gas flow rate } \\
\text { (ml/min.) }\end{array}$ & $\begin{array}{c}\text { Total yield of B(a)P } 350-850^{\circ} \mathrm{C} \\
\text { (ng/g cellulose) }\end{array}$ \\
\hline 85 & 560 \\
285 & 810 \\
500 & 1,340 \\
1,050 & 1,080 \\
\hline
\end{tabular}

TABLE 9

Graduated heating in nitrogen: Efiect of iron additives

\begin{tabular}{l|c} 
Compound pyrolyzed & $\begin{array}{c}\text { Total B(a)P yield } \\
350-850^{\circ} \mathrm{C} \\
(\mathrm{ng} / \mathrm{g} \text { cellulose) }\end{array}$ \\
\hline Cellulose (control) & 560 \\
Cellulose $+10 \%$ iron oxide & 570 \\
Cellulose $+10 \%$ iron powder & 850 \\
CMC (control) & 370 \\
CMC Ferrous Salt & 410 \\
Cellulose (control) & 550 \\
Cellulose $+10 \%$ ferricinium chloride & 18 \\
Cellulose $+2 \%$ ferricinium chloride & 325 \\
\hline
\end{tabular}

thermal pyrolysis experiments.

It appeared that the graduated heating caused a very different type of $\mathrm{B}(\mathrm{a}) \mathrm{P}$. formation reaction to take place which did not involve volatile, gaseous intermediates; for increased flow would certainly reduce $B(a) P$ yield, if volatiles were involved. These $B(a) P$ precursors appeared to be nonvolatile being formed from the solid state decomposition of cellulose.

The destruction of $\mathrm{B}(\mathrm{a}) \mathrm{P}$ at the low flow rate (85 $\mathrm{ml} / \mathrm{min}$.) was demonstrated by heating cellulose plus added B(a)P. Only $38 \%$ of the added hydtocarbon was recovered in the pyrolyzate. When the voldtility of $B(a) P$ was decreased further by adsorption on charcoal, none was recovered.

Graduated Heating Experiments with Iron Additives Mixtures of cellulose plus iron and cellulose plus iron oxide were heated to $850^{\circ} \mathrm{C}$. The $B(a) P$ yields (Table g) were not reduced below the control value; in fact, the yield with iron powder was somewhat greater. 
Graduated Heating in Different Carrier Atmospheres. The substitution of other gases for the nitrogen carrier gas was explored. The gases used were air, carbon dioxide, hydrogen, nitric oxide, and propylene. An attempt was made to include steam as one of the carrier gases. This was done by heating cellulose from $30^{\circ} \mathrm{C}$ to $850^{\circ} \mathrm{C}$ with a nitrogen gas flow of $85 \mathrm{ml}$ per minute while water was added to the pyrolysis tube from a dropping funnel at a rate of about I $\mathrm{ml}$ per minute throughout the reaction. Results are given in Table 10.

TABLE 10

Graduated heating of cellulose in various atmospheres

\begin{tabular}{|c|c|c|c|c|c|c|}
\hline \multirow{2}{*}{$\begin{array}{l}\text { Carrier gas } \\
(85 \mathrm{ml} / \mathrm{min} \text {.) }\end{array}$} & \multicolumn{6}{|c|}{$\begin{array}{c}\mathrm{B}(\mathrm{a}) \mathrm{P} \text { yield in temperature ranges }{ }^{\circ} \mathrm{C} \\
\text { ( } \mathrm{ng} / \mathrm{g} \text { cellulose) }\end{array}$} \\
\hline & $350-450$ & $450-550$ & $550-650$ & $650-750$ & $750-850$ & Total \\
\hline $\begin{array}{l}\text { Nitrogen } \\
\text { Air } \\
\text { Hydrogen } \\
\text { Nitric oxide } \\
\text { Propene } \\
\text { Carbon dioxide } \\
\text { Water }(1 \mathrm{ml} / \mathrm{min} \text {.) }\end{array}$ & $\begin{array}{r}210 \\
300 \\
250 \\
30 \\
400 \\
290 \\
\text { none }\end{array}$ & $\begin{array}{r}160 \\
180 \\
300 \\
\text { none } \\
1,100 \\
410 \\
980\end{array}$ & $\begin{array}{r}90 \\
100 \\
210 \\
\text { none } \\
26,000 \\
110 \\
1,660\end{array}$ & $\begin{array}{r}50 \\
90 \\
50 \\
\text { none } \\
95,000 \\
70 \\
370\end{array}$ & $\begin{array}{r}50 \\
60 \\
55 \\
\text { none } \\
\frac{100}{300}\end{array}$ & $\begin{array}{r}560 \\
730 \\
865 \\
30 \\
- \\
980 \\
3,310\end{array}$ \\
\hline
\end{tabular}

When air was used, the total $B(a) P$ yield was somewhat higher than it was in nitrogen. This result was the same as that observed with air in the isothermal pyrolyses and again suggests the futility of trying to reduce the yield of $\mathrm{B}(\mathrm{a}) \mathrm{P}$ by supplying additional oxygen to the pyrolysis.

Carbon dioxide and hydrogen nearly doubled the $\mathrm{B}(\mathrm{a}) \mathrm{P}$ yield with the maximum being in the $450^{\circ} \mathrm{C}$ to $550^{\circ} \mathrm{C}$ range. Water caused a sixfold increase in $\mathrm{B}(\mathrm{a}) \mathrm{P}$ yield. No acceptable hypothesis for explaining these increases is evident.

Propylene was used as a carrier gas because in pyrolyses in the $100^{\circ} \mathrm{C}$ to $400^{\circ} \mathrm{C}$ range it is reported (2) to act as an inhibitor, similar to nitric oxide. We observed, however, enormous yields of $\mathrm{B}(\mathrm{a}) \mathrm{P}$ which must have come from pyrolysis of the propylene itself.

When nitric oxide was used as a carrier gas, $B(a) P$ formation was barely detectable $(30 \mathrm{ng} / \mathrm{g}$ of cellulose). Because nitric oxide is a well-known inhibitor of free radical processes, there is reason to propose that a similar process occurred in this cellulose pyrolysis with nitric oxide.

To establish the mechanism of the effect of nitrate additives, cellulose mixed with sodium nitrite (a substance known not to evolve NO) was heated from $30^{\circ} \mathrm{C}$ to $850^{\circ} \mathrm{C}$, as was cellulose mixed with $\mathrm{MM}-\mathrm{x}^{*}$ (a mixture we found to evolve oxides of nitrogen sharply. at $425^{\circ} \mathrm{C}$ ). With sodium nitrite a slight decrease in $B(a) P$ yield was observed, but with $M M-1$ there was a decrease in total $\mathrm{B}(\mathrm{a}) \mathrm{P}$ yield of $39 \%$ (Table II).

The amounts of $\mathrm{B}(\mathrm{a}) \mathrm{P}$ collected in the various temperature ranges showed that the decrease when using $\mathrm{MM}-1$ was due mainly to a decreased formation of $\mathrm{B}(\mathrm{a}) \mathrm{P}$ in the $350^{\circ} \mathrm{C}$ to $450^{\circ} \mathrm{C}$ range. It was evident that the additive was preventing the formation of $B(a) P$ only in the temperature range in which the additive decomposed.

Free-Radical Nature of the Low Temperature Reaction These experiments with nitric oxide made it appear that this low-temperature process involved a free-radical mechanism. The experiments with propylene to be described next reinforced this conclusion.

Propylene, when pyrolyzed isothermally at $550^{\circ} \mathrm{C}$, yielded no detectable amount of $\mathrm{B}(\mathrm{a}) \mathrm{P}$ although at higher temperatures it gave abundant yields of $B(a) P$. When propylene was passed over cellulose while the temperature was raised from room temperature to $700^{\circ} \mathrm{C}$, the

TABLE 11

Graduated heating of cellulose in nitrogen: Effect of nitrogen oxides

\begin{tabular}{|c|c|c|c|}
\hline \multirow[b]{2}{*}{$\begin{array}{c}\text { Temperature } \\
\text { ranges, }{ }^{\circ} \mathrm{C}\end{array}$} & \multicolumn{3}{|c|}{ B(a)P yield ( $\mathrm{ng} / \mathrm{g}$ cellulose) } \\
\hline & $\begin{array}{l}\text { Cellulose } \\
\text { (control) }\end{array}$ & $\begin{array}{c}\text { Cellulose } \\
+10 \% \\
\mathrm{NaNO}_{2}\end{array}$ & $\begin{array}{c}\text { Cellulose } \\
+10 \% \\
M M-1\end{array}$ \\
\hline $\begin{array}{l}350-450 \\
450-550 \\
550-650 \\
650-750 \\
750-850\end{array}$ & $\begin{array}{r}210 \\
160 \\
90 \\
50 \\
50\end{array}$ & $\begin{array}{r}170 \\
110 \\
60 \\
40 \\
56\end{array}$ & $\begin{array}{r}60 \\
140 \\
100 \\
30 \\
10\end{array}$ \\
\hline TOTAL & $\overline{560}$ & $\overline{436}$ & $\overline{340}$ \\
\hline
\end{tabular}

* $\mathrm{KNO}_{2}: \mathrm{KNO}_{3}: \mathrm{Cr}_{2} \mathrm{O}_{3}: \mathrm{Fe}_{2} \mathrm{O}_{3}=6.38: 2.52: 7.6: 12.0$ (3) 
propylene, was converted to $\mathrm{B}(\mathrm{a}) \mathrm{P}$ at temperatures as low as $400^{\circ} \mathrm{C}$. The data are given in Table 12 . A probable explanation was that the cellulose decomposed in the $350^{\circ} \mathrm{C}$ to $450^{\circ} \mathrm{C}$ range with the formation of radicals, which were capable of initiating the reaction of propylene. In the absence

TABLE 12

Graduated heating experiments: Effect of propylene

\begin{tabular}{|c|c|c|c|c|c|}
\hline \multirow{2}{*}{$\begin{array}{l}\text { Material } \\
\text { pyrolyzed }\end{array}$} & \multirow{2}{*}{$\begin{array}{c}\text { Carrier } \\
\text { gas }\end{array}$} & \multicolumn{4}{|c|}{ B(a)P formed (ng) } \\
\hline & & $350-450$ & $450-550$ & $550-650$ & $650-700$ \\
\hline $\begin{array}{l}5 \mathrm{~g} \text { cellulose } \\
\text { Nothing } \\
5 \mathrm{~g} \text { cellulose }\end{array}$ & $\begin{array}{c}\text { Nitrogen } \\
\text { Propylene } \\
\text { Propylene }\end{array}$ & $\begin{array}{l}1,065 \\
\text { none } \\
2,000\end{array}$ & $\begin{array}{r}800 \\
\text { none } \\
2,700\end{array}$ & $\begin{array}{r}450 \\
24,200 \\
23,500\end{array}$ & $\begin{array}{r}250 \\
79,000 \\
119,000\end{array}$ \\
\hline
\end{tabular}
of cellulose this low temperature initiation was not possible; however, at much higher temperatures the propylene decomposed by thermal cleavage. Thus, the induced reaction of propylene by decomposing cellulose gave evidence of the production of radicals capable of initiating the conversion of propylene to $B(a) P$.

Experiments on Substances Other than Cellulose

The experiments reported thus far were all carried out with cellulose; however, in an earlier experiment the carboxymethylcellulose control sample gave $370 \mathrm{ng} / \mathrm{g}$ of $\mathrm{B}(\mathrm{a}) \mathrm{P}$ compared with $570 \mathrm{ng} / \mathrm{g}$ of $\mathrm{B}(\mathrm{a}) \mathrm{P}$ from cellulose. Thus, it appeared that the amount of $\mathrm{B}(\mathrm{a}) \mathrm{P}$ formed from two quite similar carbohydrates could vary considerably.

Cellulose was taken as the basic molecule, and the following structural changes were studied: the stereochemistry of the $C_{1}-C_{4}$ glycoside link, the nature of the substituent on $C_{5}$, and the molecular weight. The results are arranged in tabular form in Table 13. In the high polymers, the $C_{1}-C_{4}$ stereochemistry affected $B(a) P$ yield. With the exception of glucuronic acid, all the

TABLE 13 Graduated heating experiments, $350^{\circ}-850^{\circ} \mathrm{C}$ : Carbohydrate structure vs. B(a)P yield

\begin{tabular}{|c|c|c|c|c|c|}
\hline \multicolumn{2}{|c|}{ Monomer } & \multicolumn{2}{|c|}{ Dimer } & \multicolumn{2}{|l|}{ Polymer } \\
\hline Compound & $\begin{array}{l}B(a) P \\
(n g / g)\end{array}$ & Compound & $\begin{array}{l}B(a) P \\
(n g / g)\end{array}$ & Compound & $\begin{array}{l}B(a) P \\
(n g / g)\end{array}$ \\
\hline$\beta$-D-glucose & 220 & $\begin{array}{l}\text { Cellobiose } \\
\text { Sucrose }\end{array}$ & $\begin{array}{l}120 \\
130\end{array}$ & Cellulose & 550 \\
\hline & & Maltose & 138 & $\begin{array}{l}\text { Amylose } \\
\text { Soluble starch }\end{array}$ & $\begin{array}{r}143 \\
80\end{array}$ \\
\hline Xylose & 175 & & & Xylan & 500 \\
\hline Glucuronic acid & 56 & & & $\mathrm{NO}_{2}$-oxidized cellulose & 103 \\
\hline
\end{tabular}

monosaccharides ( $\beta$-glucose, dextrose and xylose) gave the same yield of $\mathrm{B}(\mathrm{a}) \mathrm{P}$ within the limits of error of the experiment. Likewise, all of the disaccharides (cellobiose, maltose, and sucrose) gave a constant yield.

Another regularity was the effect of converting the $\mathrm{C}_{6}$-hydroxymethylene group to carboxyl. In both the polymer and monomer this change caused an $80 \%$ decrease in $B(a) P$ yield. It was found in later experiments with pectic substances and with other nitrogen dioxide-oxidized

TABLE 14

Graduated heating experiments, $350^{\circ}-850^{\circ} \mathrm{C}$ in nitrogen: Effect of physical form

\begin{tabular}{c|c|c}
\hline Physical form & \multicolumn{2}{|c}{$\mathrm{B}(\mathrm{a}) \mathrm{P}$ yield (ng/g) } \\
\cline { 2 - 3 } & From cellulose & $\begin{array}{c}\text { From } \mathrm{NO}_{2} \text {-oxidized } \\
\text { cellulose }\end{array}$ \\
\hline Powder & 550 & 103 \\
Paper & 418 & $\overline{53}$ \\
Gauze & 268 & 53 \\
\hline
\end{tabular}
materials that this was quite general. Table 14 illustrates that a change in physical form affected the yield of $\mathrm{B}(\mathrm{a}) \mathrm{P}$ from the chemically altered cellulose to about the same extent that it did the control. 
These experiments have led to the conclusion that large quantities of $B(a) P$ can be formed by high temperature $\left(850^{\circ} \mathrm{C}\right)$ isothermal pyrolysis of cellulose through a very efficient gaseous reaction route. In this reaction the $\mathrm{B}(\mathrm{a}) \mathrm{P}$ yield decreased in the presence of iron, cobalt, and nickel while the yield increased with increasing temperatures and with the introduction of oxygen into the system.

In contrast, the graduated heating experiments demonstrated that $\mathrm{B}(\mathrm{a}) \mathrm{P}$ was formed from cellulose at temperatures as low as $450^{\circ} \mathrm{C}$. This reaction was inefficient with respect to $B(a) P$ yield and was unaffected by the presence of metals. The $\mathrm{B}(\mathrm{a}) \mathrm{P}$ precursors were hypothesized to be nonvolatile, being formed via a solid state decomposition of cellulose and involving the generation of free radicals. This reaction was inhibited by the presence of nitric oxide or salts generating nitric oxide. Additionally, oxidation of the cellulose molecule at the Co position produced a decreased $B(a) P$ yield.

One final point of interest relates to the quantity of $\mathrm{B}(\mathrm{a}) \mathrm{P}$ reportedly present in cigaret smoke (4). If, for example, one considers the filtration efficiency of cut tobacco filler per unit length of cigaret rod and the amount of the cigaret consumed during static burning, the reported yield of $\mathrm{B}(\mathrm{a}) \mathrm{P}$ is about 130 to $150 \mathrm{ng}$ per gram of tobacco smoked in the normal way. The yield of $\mathrm{B}(\mathrm{a}) \mathrm{P}$ from the isothermal pyrolysis of cellulose at $880^{\circ} \mathrm{C}$ (approximately the coal temperature of a cigaret) was 1,000 times greater than that reported from a burning cigaret. Obviously, conclusions drawn from studies conducted under experimental conditions similar to isothermal pyrolysis at $850^{\circ} \mathrm{C}$ should not be extrapolated to the pyrolytic conditions which exist in a burning cigaret.

SUMMARY

The purpose of this study was to learn how cellulose pyrolysis was affected by changes in atmospheres, by varied pyrolysis temperatures, by the addition of inorganic materials, and by chemical modifications of the cellulose molecule.

These studies have led to the hypothesis that cellulose can pyrolyze by two different modes to form $B(a) P$. Large quantities of $B(a) P$ can be formed by high temperature $\left(850^{\circ} \mathrm{C}\right)$ isothermal pyrolysis of cellulose via a very efficient gaseous reaction route. In this reaction the $B(a) P$ yield decreased in the presence of iron, cobalt, and nickel while the yield increased with increasing temperatures and with the introduction of oxygen into the system.

In contrast, graduated heating experiments demonstrated that $B(a) P$ began to form at $450^{\circ} \mathrm{C}$. This reaction was inefficient with respect to $B(a) P$ yield and was unaffected by the presence of metals. The $\mathrm{B}(\mathrm{a}) \mathrm{P}$ precursors were hypothesized to be nonvolatile, being formed via a solid state decomposition of cellulose and irivolving the generation of free radicals. This reaction was inhibited by the presence of nitric oxide or salts generating nitric oxide. Additionally, oxidation of the cellulose molecule at the $\mathrm{C}_{6}$ position produced a decreased $\mathrm{B}(\mathrm{a}) \mathrm{P}$ yield.

ZUSAMMENFASSUNG

Die Pyrolyse von Cellulose wurde in Abhängigkeit von einer Veränderung der Luftzusammensetzung, von unterschiedlichen Temperaturen, vom Zusatz anorganischer Stoffe und von chemischen Veränderungen des Cellulosemoleküls untersucht.

Aus den Untersuchungen wurde die Hypothese abgeleitet, daß die Pyrolyse von Cellulose und die mit ihr verbundene Bildung von Benz(a)pyren auf zwei verschiedenen Wegen verlaufen kann. Große Mengen von Benz(a)pyren können bei isothermer Pyrolyse von Cellulose bei hohen Temperaturen $\left(850^{\circ} \mathrm{C}\right)$ durch eine sehr wirksame Gasphasenreaktion entstehen. Bei dieser Reaktion verminderte sich die Benzpyrenausbeute in Gegenwart von Eisen, Kobalt und Nickel, während die Ausbeute bei Erhöhung der Temperaturen und bei Zuführung von Sauerstoff anstieg.

Im Gegensatz zu diesen Befunden ging aus Versuchen mit einer stufenweise durchgeführten Erhöhung der Temperatur hervor, daB sich Benz(a)pyren bei $450^{\circ} \mathrm{C} z \mathrm{zu}$ bilden beginnt. Diese Reaktion ergab keine sehr hohe Benzpyrenausbeute und wurde durch die Gegenwart von Metallen 


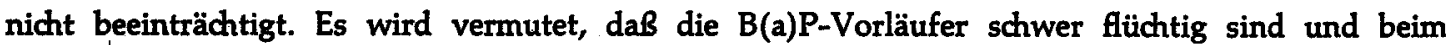
Abbau der Cellulose aus dem festen Aggregatzustand unter Bildung freier Radikale entstehen. Diese Reaktion wurde in Gegenwart von Stickoxiden oder von Salzen, aus denen diese Oxide gebildet werden, gehemmt. Außerdem führte die Oxydation des Cellulosemoleküls in $\mathrm{C}_{6}$-Stellung zu einer geringeren Ausbeute an Benz(a)pyren.

RESUME

La présente étude se propose d'élucider les effets qu'ont sur la pyrolyse de la cellulose les modifications d'atmosphères, les diverses températures de pyrolyse, l'addition de matières inorganiques et les modifications chimiques de la molécule de cellulose.

Ces études ont conduit d̀ l'hypothèse que la cellulose peut se pyrolyser suivant deux modes différents pour former du B(a)P. De grandes quantités de B(a)P peuvent être formées par une pyrolyse isothermique de la cellulose à haute température $\left(850^{\circ}\right)$ suivant une voie de réaction gazeuse très efficace. Dans cette réaction, le rendement en $\mathrm{B}(\mathrm{a}) \mathrm{P}$ décroît en présence de $\mathrm{Fe}$, Co et $\mathrm{Ni}$, alors qư'il croît pour des températures croissantes et avec l'introduction de $\mathrm{O}_{2}$ dans le système.

A l'opposé, des expériences de chauffage graduel ont démontré que le B(a)P commence à se former à $450^{\circ} \mathrm{C}$. Cette réaction a un mauvais rendement en $\mathrm{B}(\mathrm{a}) \mathrm{P}$ et n'est pas affectée par la présence de métaux. On suppose que les précurseurs du $B(a) P$ ne sont pas volatils, prenant naissance via une décomposition de la cellulose à l'état solide et comportant la production de radicaux libres. La réaction est inhibée par la présence de $\mathrm{NO}_{2}$ ou de sels engendrarit du $\mathrm{NO}_{2}$ : De plus, l'oxydation de la molécule de cellulose sur la position $C_{b}$ abaisse le rendement en $B(a) P$.

REFERENCES

1. Robb, E. W.; Guvernator, G. C., Edmonds, M. D., and Bavley, A.: Beitr. Tabakforsch. 3 (1965) 278.

2. Ashmore, P. G.: Catalysis and Inhibition of Chemical Reaction, Butterworth \& Co. Ltd., 1963, p. 279.

3. Jolly, W. L.: Synthetic Inorganic Chemistry, Prentice-Hall Inc., 1960, p. 189.

4. Bentley, H. R., and Burgan, J. G. : Analyst 83 (1958) 442.

Acknowledgment

The authors wish to thank Philip Morris Inc. for permission to publish this work and want to acknowledge the aid of Mr. John Kang in carrying out pyrolyses and of Mr. Frank Greene in conducting fluorescence measurements.

The authors' address:

Philip Morris Inc., Research Center, P. O. Box 3 D, Richmond, Va., 23206, USA 